PART II. PHYSICAL ACTIVITY OF SOCIAL AND PROFESSIONAL GROUPS DZIAŁ II. AKTYWNOŚĆ FIZYCZNA GRUP SPOŁECZNYCH I ZAWODOWYCH

\title{
PERSONALIZED REHABILITATION THERAPY IN OBESE AND ELDERLY PATIENTS UNDERGOING HIP REPLACEMENT SURGERY
}

\section{PERSONALIZACJA REHABILITACJI U OSÓB OTYŁYCH ORAZ W PODESZŁYM WIEKU PODDANYCH ZABIEGOWI ENDOPROTEZOPLASTYKI STAWU BIODROWEGO}

\author{
Michał Skalski $^{1(\mathrm{~A}, \mathrm{E}, \mathrm{F})}$, Milena Socha-Kania ${ }^{2(\mathrm{E}, \mathrm{F})}$, Maria Kozioł-Montewka $^{(\mathrm{E})}$, Anna Pańczuk ${ }^{4(\mathrm{E})}$
}

${ }^{1}$ The Independent Group of Public Ambulatory Care Institutions No. 1, Wawer, Warsaw, Poland

${ }^{2}$ Fitness Club Olimpia Lublin, Poland

${ }^{3}$ Department of Public Health, Pope John Paul II State School of Higher Education in Biała Podlaska, Poland

${ }^{4}$ Department of Physiotherapy, Pope John Paul II State School of Higher Education in Biała Podlaska, Poland

Authors' contribution

Wkład autorów:

A. Study design/planning zaplanowanie badań

B. Data collection/entry zebranie danych

C. Data analysis/statistics dane - analiza i statystyki

D. Data interpretation interpretacja danych

E. Preparation of manuscript przygotowanie artykułu F. Literature analysis/search wyszukiwanie i analiza literatury G. Funds collection zebranie funduszy

\section{Summary}

Due to aging of the population and the desire of people to maintain the best possible mobility, the demand for hip replacement is increasing. As a result, personalization of physical therapy after surgery is needed to achieve the best possible outcomes. However, patients undergoing hip replacement surgery often have additional factors, such as advanced age and obesity, which may hinder the process of rehabilitation. The aim of this study was to review the need and recommendations for personalized physical therapy before and after hip replacement surgery in patients with co-morbid factors such as advanced age and obesity. The research literature emphasizes the importance of effective recovery following hip replacement surgery. Older patients may require prolonged postoperative rehabilitation due to the type of surgery, muscle weakness or cognitive dysfunction. Proprioception and balance disorders may benefit from training on an unstable surface aimed at learning safe falling and getting up after a fall. Weakened gluteal muscles which may be present in the elderly and obese may benefit from strength training in the preoperative period. Excessive exposure of the elderly and obese to thromboembolic complications necessitate the inclusion in rehabilitation programs of exercises based on active ankle movement.

Keywords: rehabilitation, arthroplasty, replacement, hip replacement

\section{Streszczenie}

Ze względu na proces starzenia się społeczeństw i dążenia do możliwie najdłuższego zachowania pełnej sprawności funkcjonalnej, zwiększa sie zapotrzebowanie na zabiegi endoprotezoplastyki stawu biodrowego. W związku z tym, pojawia się konieczność personalizacji procesu usprawniania związanego $\mathrm{z}$ zabiegiem $\mathrm{w}$ celu osiągnięcia jak najlepszych końcowych wyników. Należy jednak pamiętać, że pacjenci poddawani zabiegowi endoprotezoplastyki stawu biodrowego często obciążeni się dodatkowymi czynnikami utrudniajacymi proces rehabilitacji w postaci zaawansowanego wieku i otyłości. Celem pracy jest zwrócenie uwagi na konieczność personalizacji procesu usprawniania przed i po zabiegu endoprotezoplastyki stawu biodrowego u chorych z dodatkowymi czynnikami obciążającymi w postaci zaawansowanego wieku i otyłości w stosunku do obowiazujacych rekomendacji i zaleceń. Najnowsza literatura badawcza szeroko dyskutuje aspekt optymalizacji procesu usprawniania po endoprotezoplastyce stawu biodrowego. Zaawansowany wiek pacjentów może wiązać się z koniecznością wydłużenia czasu rehabilitacji pooperacyjnej. Wynika to z rodzaju dostępu operacyjnego, osłabienia siły mięśniowej czy zaburzeń funkcji poznawczych. Zaburzenia propriocepcji i równowagi przekonują do zastosowania elementów rehabilitacji funkcjonalnej $\mathrm{z}$ elementami treningu równoważnego na niestabilnym podłożu, nauki bezpiecznego upadania i wstawania po upadku. Osłabienie siły mięśnia pośladkowego średniego obecne wśród pacjentów starszych i otyłych sugeruje, że wymierne korzyści może mieć stosowanie treningu wzmacniającego jeszcze w okresie przedoperacyjnym. Szczególne narażenie osób starszych i otyłych na powikłania zakrzepowo-zatorowe skłania natomiast do starannego wykonywania ćwiczeń opartych na aktywnym ruchu stawu skokowego.

Słowa kluczowe: rehabilitacja, artroplastyka, endoprotezoplastyka, endoprotezoplastyka

stawu biodrowego
Tables: 0
Figures: 0

References: 37

Submitted: 2017 Nov 28

Accepted: 2018 Jan 25

Skalski M, Socha-Kania M, Kozioł-Montewka M, Pańczuk A. Personalized rehabilitation therapy in obese and elderly patients undergoing hip replacement surgery. Health Prob Civil. 2019; 13(3): 193-200. https://doi.org/10.5114/hpc.2018.80597

Address for correspondence / Adres korespondencyjny: Milena Socha-Kania, Fitness Club Olimpia Lublin, Pogodna 28a, 20-315 Lublin, Poland,

e-mail: milena.socha@yahoo.com, phone: +48 667559 894; ORCID: Anna Pańczuk https://orcid.org/0000-0002-6628-0573

Copyright: (C) Pope John Paul II State School of Higher Education in Biała Podlaska, Michał Skalski, Milena Socha-Kania, Maria Kozioł-Montewka, Anna Pańczuk. This is an Open Access journal, all articles are distributed under the terms of the Creative Commons Attribution-NonCommercial-ShareAlike 4.0 International (CC BY-NC-SA 4.0) License (http://creativecommons.org/licenses/by-nc-sa/4.0/), allowing third parties to copy and redistribute the material in any medium or format and to remix, transform, and build upon the material, provided the original work is properly cited and states its license. 


\section{Introduction}

The evolution of society brings not only ubiquitous technical and medical benefits, but also serious health problems. Among them, degenerative joint diseases are an important problem resulting, in part, from a sedentary life style and which can, in turn, lead to other health problems, such as obesity. At the same time, we are living longer and we expect that modern medicine will allow us to function well into old age.

One of the ways to optimize recovery following hip replacement is a personalized rehabilitation program, taking into account the co-morbid conditions of advanced age and obesity commonly found in people suffering from joint disease. The two main conditions discussed in this study (older age and obesity) are related to a number of complications of hip replacement surgery including the more frequent need for revision, infection, loosening of the prosthesis, muscle weakness, balance disorders, reduced ability to concentrate and learn and depression $[1,2,3,4,5]$.

The physical therapy programs currently proposed in the context of hip replacement surgery require solutions that take into account the individual needs of each patient. The program is not only postoperative but also preoperative to identify patients who require special interventions.

\section{Data justifying the need for personalization of rehabilitation programs}

Hip degeneration is the most common form of degenerative disease. Its frequency differs between countries. In Poland $40 \%$ of the population have hip degeneration and in Europe and the USA it is 12\% [6].

In Poland, 39,854 hip arthroplasty procedures were performed in 2010, and, in 2015, the number of procedures was 46,685 [7]. Internationally, it is expected that the number of hip replacements will increase by $170 \%$ by 2030, and that increase will likely be mirrored in Poland [4].

The frequency of osteoarthritis increases with age and is over $60 \%$ among people over the age of 65 . Given the widespread phenomenon of aging in Europe, osteoarthritis will be a major social problem in the coming decades [8].

A report commissioned by the Ministry of Health in 2015 indicates that the most common reasons for hip replacement ( $89 \%$ of cases) were bilateral osteoarthritis, hip fracture and other forms of arthritis. Revision is most often caused by mechanical complications related to the prostheses, including loosening and infections, and the incidence of complications increases with aggravating factors such as age, obesity or diabetes that increases the risk of infection [7]. According to data from 2015, most surgeries were performed in patients aged 60-69 and 70-79, accounting for 58\% of all treatments [7, 9].

Numerous research studies have focused on obesity as a contributor to degeneration of the hip and to postoperative complications. The estimated number of patients with obesity varies in research studies from $41 \%$ to $77 \%[5,9,10,11,12]$.

The main treatment of osteoarthritis is hip replacement, supplemented by preoperative and postoperative rehabilitation. As the condition mainly occurs in the elderly, the presence of other factors complicating treatment should be considered. In addition to older age, diabetes, obesity and other co-morbid conditions are common in this group of patients. These aggravating factors underscore the need for personalized physical therapy. An individual approach to each patient, appropriate to his or her current state of health, will permit for the best possible outcome in the shortest possible time.

\section{Objective}

The aim of this work was to review the role of and recommendations for personalized physical rehabilitation before and after hip replacement in patients with additional risk such as advanced age and obesity.

\section{Recommendations for physical rehabilitation in people undergoing hip replacement}

In individual countries, recommendations for physical therapy in persons undergoing hip replacement differ. There are no uniform guidelines for the timing of rehabilitation post-surgery or after discharge from the orthopedic department, or for specific techniques for use in elderly and obese people.

The Global Orthopedic Registry (GLORY) reports that the postoperative hospital stay in the US is 3 days, in Great Britain it is 9 days, in Germany 11 days, and in Japan up to 30 days [13]. Recommendations for physical therapy range from a few days to 2-4 weeks after leaving the orthopedic department. The rehabilitation program focuses on an individual and group occupational therapy as well as functional exercises. 
Recommendations from the USA and Canada emphasize the importance of functional strengthening exercises, working in the active range of movement and walking up stairs. Similar recommendations follow recent studies among physiotherapists in Great Britain and the Netherlands [14, 15].

The Polish model of comprehensive care for hip replacement is based on data from the analysis provided by the NFZ Headquarters (National Health Fund), other scientific evidence and expert opinion, in addition to financing data from other countries. The first stage is preoperative care, which includes assessment of eligibility for surgery, selection of the optimal preoperative physical therapy and, if necessary, consultation with physicians of other specialties. At this stage of preparation, patients receive education on the planned stay in the hospital, the use of orthopedic supplies after the procedure, instructions on what movements should not be performed and the overall rehabilitation plan. The patient is also informed on how to adapt the home environment to minimize the risk of complications.

The second stage is hospitalization, during which the patient is directly prepared for the procedure, usually commencing one day before the planned operation. The patient's rehabilitation begins with mobilization on the first day following surgery. The usual time of hospitalization is 5 days, and in the case of elderly people with comorbidities, it is prolonged. During this time, further rehabilitation and patient education take place (outpatient, stationary, home, daily).

The third stage is the post-hospital period, which includes 2-3 therapy visits. During this time, decisions about the scope and timing of further rehabilitation are made. The NFZ model provides for one stay in a day rehabilitation ward and one stay in an outpatient rehabilitation facility in the first one year following the procedure [7].

The recommendations do not take into account individual patient needs. These result from the often advanced age and co-morbid conditions of patients undergoing hip replacement surgery. Similarly, there are patients with obesity who are at risk for more complications and whose regenerative abilities are reduced. The presence of these risk factors significantly affects the outcomes of therapy and should be considered during the planning phase.

\section{Considerations for older people undergoing arthroplasty}

Older people require a special approach when preparing for the procedure. After establishing the indications and contraindications for rehabilitation in the pre-operative period, a rehabilitation plan should be introduced, tailored to the patient's needs, preparing for weight bearing and temporary post-operative relative inactivity. Depending on the individual level of functional fitness, the following general exercises are performed: conditioning exercises, simulation of the post-operative situation, learning to change position in bed, self-care and antithrombotic exercises. Particularly important during this period is general exercise to counteract the negative effects of postoperative relative inactivity. They can take the form of various types of endurance training, from walks to exercises on a cycloergometer or treadmill with intensity adjusted to the patient's performance [16].

A separate category of patients are those who, due to coexisting disorders, require an individualized approach. These are people with postural defects or limitations of joint mobility, chronic respiratory diseases, hearing and visual impairment, and reduced cognitive and intellectual abilities [16].

The natural aging process is associated with reduced regenerative ability following surgery. With age, neuromuscular coordination, balance, defensive reactions and cognitive functions deteriorate. Additionally, osteoporosis and muscle loss commonly present in elderly patients.

Research conducted in Japan in the elderly following hip and knee arthroplasty, showed that patients aged 65 and over who underwent surgery reported a reduced quality of life due to pain and the risk of falls. These results emphasize that people over the age of 65 have a much greater risk of falls, necessitating an individually tailored physical therapy program [17].

An unfavorable prognosis among the oldest patients is also associated with impaired cognitive function. In the same research from Japan, it was shown that personalized physical training contributed to a decrease in depressive moods and a more rapid increase in fitness among patients with impaired cognition, giving patients an improved chance to continue a healthy and high-quality life. There was also a correlation between intensive post-operative rehabilitation and improvement in gait within a short time after the procedure. In the event of early discharge from the hospital, the task of the therapist is to teach the patient how to improve gait function at home. Available literature suggests that the greatest improvement in health-related quality of life occurs shortly after surgery, but peak times differ. Some sources report that patients improved after 6 months after surgery and maintained improvement for up to 4 years, while other studies report that peak improvement was achieved after one year and declined within 7 years [17]. 
There are concerns about the deterioration of cognitive function and the occurrence of delirium among older patients, making diagnosis with simple screening tests such as MMSE (Mini-Mental State Examination) important. It is known, however, that motion therapy has a beneficial effect on cognitive function and general mental health [17].

Among the adult population, hip fractures are the result of high energy injuries, and the peak occurrence is among older people. As a result of the aging process and widespread osteoporosis in the elderly, fractures of the femoral neck are caused by low-energy injuries [18]. The estimated survival rate after femoral fractures among older people is $23.3 \%$ for men and $11.2 \%$ for women [19].

Older people are often at risk of falls caused by balance disorders, mental illness, medications, visual disturbance and the inability to adapt to the external environment. Considering disorders of coordination and defense mechanisms in the elderly and the reduction of bone density, the risk of fracture is high [20].

Scientific evidence suggests that hip replacement is the treatment of choice among patients with a high level of fitness, and numerous studies confirm that this procedure allows recovery with improved fitness and quality of life. Post-operative rehabilitation shortens the time of hospitalization, reduces the occurrence of complications, improves functional efficiency and reduces the need for third party assistance [20]. In addition, special attention should be paid to the overall care of the patient, taking into account other conditions that may coexist in older patients such as anemia, chest or urinary tract infections, undiagnosed heart problems or dementia. The complexity of the problem requires a holistic approach and involvement of geriatricians in order to minimize the risk of complications associated with co-morbidities [20].

Research suggests that hip replacement in the case of hip fracture is a procedure that provides faster recovery, better functional improvement and reduces the number of complications compared to the internal anastomosis procedure. However, there are reports of increased initial costs of treatment and greater blood loss during surgery as well as an increased risk of dislocation and infection [20]. Replacement is associated with a greater than $90 \% 10$ year survival with reduced postoperative pain and the need for revision of the surgery due to acetabular pain due to erosion [21].

The group of patients above 80 years of age is particularly prone to postoperative complications and hospital readmission. In this age group, treatment models based on intensive rehabilitation and as short as possible hospitalization time may not be applicable. Due to existing comorbidities, these patients require measures adjusted individually to their condition, which often translates into longer hospital stays or longer rehabilitation after discharge [22].

\section{Obesity in the context of replacement procedures}

Obesity is associated with complications due to a higher weight-bearing burden compared to patients with normal body weight. It is also more difficult to restore normal walking patterns due to inadequate muscle strength of the pelvic girdle.

In the era of sedentary lifestyles, we observe a continuous increase in the number of people with obesity, which leads to the acceleration of the development of osteoarthritis, resulting in a reduction in the age of patients undergoing hip replacement [23]. Obesity is also a serious burden on the body during the procedure and subsequent rehabilitation, which often involves the need to extend the time of hospitalization and adapt the rehabilitation plan.

It is estimated that significant weight loss in a year after surgery occurs in $14-49 \%$ of patients. It seems logical, therefore, to encourage patients to reduce their weight before surgery. However, they have other conditions such as diabetes or thyroid disease, which hinder the weight reduction process. In addition, vitamin D deficiencies, which increase susceptibility to fractures, are common among postmenopausal women [24].

The preparation of obese people for hip replacement includes not only weight reduction and bone reinforcement but also preparation of the circulatory and respiratory systems for the increased post-operative workload. Therefore, pre-operative rehabilitation should include exercises involving large muscle groups that increase general joint mobility, exercises with moderate resistance to stimulate the skeletal system and conditioning exercises adjusted to the individual patient's capabilities that increase cardiovascular and respiratory efficiency [25].

Research conducted among patients with different BMI (Body Mass Index) values underscores that people suffering from morbid obesity (BMI> 50) are exposed to significantly more serious postoperative complications, including the need for early reoperation, which entails higher costs [26]. According to retrospective studies that assess the presence of twelve increasingly serious complications during the first 90 days following surgery, patients with morbid obesity are much more likely to be exposed to implant infections, need for revision, 
wound dehiscence, deep vein thrombosis, pulmonary embolism, implant failure, acute renal failure, myocardial infarction and implant dislocation [27].

\section{Personalization of the rehabilitation program}

In the era of global aging and increasing incidence of social morbidities, including obesity, the priority is to develop new rehabilitation guidelines that will optimize the rehabilitation process, reduce treatment costs and ensure that the patient has the best possible function in everyday life. Personalization of the rehabilitation process is essential to achieving the best outcomes. There has been a discussion in the literature for a long time on modifying rehabilitation strategies, but there are no clear guidelines for the management of patients with specific illnesses such as obesity, diabetes or other age related conditions.

It has been shown that, one year after the procedure, $50 \%$ of patients who underwent hip and knee hip replacement did not show clinically significant differences in the scale of perceived pain and activities of daily living (ADL). At the same time, it was shown that systematic training in people with osteoarthritis effectively reduced pain and improved ADL scores. Studies of the effectiveness of an 8-week pre-surgery training program showed a tendency to shorter time of hospitalization, and thus the costs of treatment. There was also a slight to moderate improvement in clinical recovery, which, however, translated into a significant improvement in quality of life. Current standards suggest that a training program of 2 to 4 week's duration, which in light of the results obtained seems to be insufficient, supports reflection on the need to extend the rehabilitation period to adequately reflect to the patient's post-operative status [28].

Subsequent studies were conducted on the basis of a two-case study (female and male) using a 6-week rehabilitation program comprising 18 sessions containing two 15-minute elements of aerobic training and a 20-minute strengthening training with 10-minute breaks between exercises. The women's training focused on improving gait function (improving speed, going uphill, and going up stairs). Therefore, a variable-gradient treadmill and an elliptical machine were used, and strengthening training employed based on walking with increasing load, walking on different surfaces and working on improving stabilization. Men were found to improve through running and playing golf. A treadmill was used with increasing speed, supplemented by training based on swinging movements of various ranges and the balls of different heaviness and simulation of the game of golf [29]. At the end of the whole cycle, the adductor's strength increased by $25 \%$ and knee extensors by $33 \%$. Compared to men, women obtained better results which were sustained for 12 months. In the second case study, results were not matched with those before the procedure, and, over third consecutive months, there was a weakening of muscle strength. This can be caused by large tissue damage associated with anterolateral lateral surgical access. Therefore, in these men consideration should be given to extending the length of the training plan. Operational access and associated tissue damage and the healing process can have a significant impact on the rehabilitation process after hip arthroplasty, necessitating an individual approach to each patient [30].

Judd et al. showed that the decrease in physical activity one month after the endoprosthetic procedure resulted in loss of muscle strength and functional deficits and decreased physical activity. Interestingly, the loss of strength in the operated limb was not limited to the muscles of the iliac girdle. Although the muscles controlling the iliac rim lost the most on endurance, the deficits were more widespread [31]. This was confirmed by the study of Readon et al., who showed that weakening of the strength of the quadriceps muscle persists within 5 months after replacement [32]. It has also been demonstrated that reduction of muscle strength of flexors, rectifiers and hip abductors lasts from several months to several years after surgery [33, 34].

However, considering that the decrease in muscle strength occurs early after surgery at the time when rehabilitation has the greatest impact, it is reasonable to support early physiotherapeutic intervention to improve long-term rehabilitation results. This will facilitate a more rapid recovery of the lost muscular strength and will facilitating better long-term outcomes of the postoperative rehabilitation [31].

An important component of the rehabilitation plan in the early period following the procedure is active ankle movements used to prevent thromboembolic complications. It has been proven that the optimum frequency of ankle movements for the flow of blood in the deep thigh vein is 60 contractions per minute. Elderly and obese people are particularly at risk of thromboembolism complications, supporting the need to perform this type of exercise with particular care and set a slightly higher intensity than in younger people with normal BMI [30].

Osteoarthritis is associated with a weakening of proprioception, i.e. a deep sensation, through which the body derives information about the position of particular parts of the body. The results of previous studies are contradictory and do not give a definite answer whether the reconstructive procedure results in the improvement or deterioration of deep sensation. In association with balance disorders common in the elderly, proprioception disorders additionally increase the risk of falls, so, in such cases, more attention needs to be paid to proprioception disorders when planning rehabilitation programs [35]. 
A study investigating changes in proprioceptive responses during a 5-week training program, which included additional exercises to improve proprioception, among patients following hip and knee arthroplasty showed a significant improvement in balance compared to the control group, which underwent only standard training [31]. This suggests that the rehabilitation process for the elderly should include broadly defined balance training, including walking on different surfaces, using devices such as a BOSU balance ball, sensomotor cushion, a ramp and training in safe falling.

In 2016, results were published of research into the impact of pre-operative atrophy of the gluteus muscles on gait disturbances occurring within 6 months after hip replacement surgery. Weakening of the iliac rim muscles leads to the fixation of abnormal gait function patterns. The patient, in order to relieve the aching joint, tilts the torso towards the other limb (with better stabilization) and in this way compensates for the failure of the abductor on the dysfunctional side during gait. The pre-operative strength of muscles stabilizing the pelvis during walking may be a determinant of postoperative improvement of gait function. Analogous studies have demonstrated the impact of pre-operative quadriceps strengthening on results obtained shortly after replacement [36].

Pain associated with the degenerative process, which contributes to a reduction in patients' activity and encourages them to relieve weight on the limb, is the main cause of muscle weakness. Screening performed before the operation to identify people with this problem will allow personalization of the rehabilitation process, taking into account existing muscle dysfunction. This will allow the setting of training goals appropriate to the patient's needs and a more rapid improvement of gait function [36]. Pre-operative training may also strengthen the middle gluteal muscles.

Obesity is one of the most important factors determining the rate of increase in muscle strength after the procedure. Patients with an increased BMI need greater abductor strength compared to patients with a normal BMI. Therefore, regaining muscle strength necessary for proper walking is much more difficult for obese patients. However, weight reduction before the procedure does not guarantee improvement in muscle strength or walking capacity [37].

Ikeda et al. in their study also focused on the importance of psychological factors in post-operative recovery. They report that depression, which often occurs in elderly and chronically ill people, extends the time of rehabilitation, limiting ADL even up to two years after surgery. Depression is also associated with a more frequent early re-operation. It is assumed that the patient's mental state and muscular strength are interrelated, and prolonged muscle weakness translates into worsening of mood due to the impaired everyday living and social life. The psychological state of patients is, therefore, another aspect that requires personalization of the rehabilitation program and, if necessary, appropriate interventions aimed at improving mental and social functioning [37].

\section{Conclusions}

In the research literature, optimizing rehabilitation therapy following hip replacement surgery is widely discussed. Many issues affect patient recovery, especially when their health is burdened by obesity and conditions associated with the aging process. Personalization of rehabilitation therapy will guarantee optimal treatment outcomes and permit satisfactory participation in day-to-day and social life.

Older patients may need an extended period of post-operative rehabilitation, which is influenced by the type of surgical access and muscle weakness due to degenerative disease or cognitive impairment. Proprioception and balance disorders also require functional rehabilitation with training on unstable ground, learning how to avoid falls and how to fall safely. The weakness of the gluteus medius present in older and obese patients suggests that the use of strengthening training in the pre-operative period may improve outcomes. The predisposition of elderly and obese people to thromboembolic complications supports the use of appropriate exercises based on active ankle movement. The importance of personalization and individualization of rehabilitation programs for persons undergoing arthroplasty is the subject of ongoing research, and educational and scientific deliberations, especially in the context of elderly and obese people.

\section{References:}

1. Zusmanovich M, Kester BS, Schwarzkopf R. Postoperative complications of total joint arthroplasty in obese patients stratified by BMI. J Arthroplasty. 2018; 33(3): 856-864. https://doi.org/10.1016/j.arth.2017.09.067

2. Goodnough LH, Finlay AK, Huddleston JI, Goodman SB, Maloney WJ, Amanatullah DF. Obesity is independently associated with early aseptic loosening in primary total hip arthroplasty. J Arthroplasty. 2018; 33(3): 882886. https://doi.org/10.1016/j.arth.2017.09.069 
3. Jørgensen OJ, Haakenstad BH, Ovesen O, Overgaard S. Clinical outcome, complications and prosthesis survival in patients operated with hip resurfacing arthroplasty. Ugeskr Laeger. 2017; 179(43): pii: V05170432.

4. Puzio G, Stopa A, Szczygielska-Babiuch A, Staszczak-Gawełda I, Krupnik S, Żak M. [Assessment of basic and instrumental activities of daily living in geriatric patients after total hip arthroplasty]. Postępy Rehabilitacji. 2014; (4): 13-20 (in Polish).

5. Dowsey MM, Liew D, Stoney JD, Choong PF. The impact of obesity on weight change and outcomes at 12 months in patients undergoing total hip arthroplasty. Med J Aust. 2010; 193(1): 17-21.

6. Dziekońska M, Latosiewicz R, Kulikowska A. [Nursing care of patients after hip joint arthroplasty]. Hygeia Public Health. 2013; 48(3): 355-359 (in Polish).

7. Agencja Oceny Technologii Medycznych i Taryfikacji Wydział Taryfikacji. [Hip replacement - complex care. Report]. Warszawa: Agnencja Oceny Technologii Medycznych i Taryfikacji Wydział Taryfikacji; 2016.261 p. No. AOTMiT-WT-553-14/2015 (in Polish).

8. Pop T, Szczygielska D, Drużbicki M, Zajkiewicz K. Epidemiology and cost of conservative treatment of patients with degenerative joint disease of the hip and knee. Ortopedia Traumatologia i Rehabilitacja. 2007; 4(6): 9: 405-409.

9. Grubor P, Manojlovic S, Manojlovic N, Grubor M. Endoprosthesis and obesity. Med Arch. 2013; 67(6): 446449. https://doi.org/10.5455/medarh.2013.67.446-449

10. Suleiman LI, Ortega G, Ong'uti SK, Gonzalez DO, Tran DD, Onyike A, et al. Does BMI affect perioperative complications following total knee and hip arthroplasty?. J Surg Res. 2012; 174(1): 7-11. https://doi.org/10.1016/j.jss.2011.05.057

11. Hurwit DJ, Trehan SK, Cross MB. New joints, same old weight: weight changes after total hip and knee arthroplasty. HSS J. 2016; 12(2): 193-195. https://doi.org/10.1007/s11420-015-9481-5

12. Waddell J, Johnson K, Hein W, Raabe J, FitzGerald G, Turibio F. Orthopaedic practice in total hip arthroplasty and total knee arthroplasty: results from the Global Orthopaedic Registry (GLORY). Am J Orthop (Belle Mead NJ). 2010; 39(9 Suppl): 5-13.

13. Peter WF, Nelissen RG, Vliet Vlieland TP. Guideline recommendations for post-acute postoperative physiotherapy in total hip and knee arthroplasty: are they used in daily clinical practice?. Musculoskeletal Care. 2014; 12(3): 125-131. https://doi.org/10.1002/msc.1067

14. Eulenburg C, Rahlf AL, Kutasow A, Zech A. Agreements and disagreements in exercise therapy prescriptions after hip replacement among rehabilitation professionals: a multicenter survey. BMC Musculoskelet Disord. 2015; 16: 185. https://doi.org/10.1186/s12891-015-0646-7

15. Sonoda Y, Sawano S, Kojima Y, Kugo M, Taniguchi M, Maegawa S, et al. Comprehensive geriatric assessment of effects of hospitalization and long-term rehabilitation of patients following lower extremity arthroplasty. J Phys Ther Sci. 2016; 28(4): 1178-1187. https://doi.org/10.1589/jpts.28.1178

16. Madejska I, Doroszewska-Szczepanik A. [Pre- and perioperative rehabilitation of elderly patients - physical rehabilitation]. Postępy Nauk Medycznych. 2008; 12: 804-810 (in Polish).

17. Singer BR, McLauchlan GJ, Robinson CM. Epidemiology of fractures in 15000 adults: the influence of age and gender. J Bone Joint Surg Br. 1998; 80: 243-248. https://doi.org/10.1302/0301-620X.80B2.7762

18. Kanis JA, Johnell O, Oden A, Sembo I, Redlund-Johnell I, Dawson A, et al. Long-term risk of osteoporotic fracture in Malmö. Osteoporosis Int. 2000; 11(8): 669-674. https://doi.org/10.1007/s001980070064

19. Antapur P, Mahomed N, Gandhi R. Fractures in the elderly: when is hip replacement a necessity?. Clin Interv Aging. 2011; 6: 1-7.

20. Marya SK, Thukral R, Singh C. Prosthetic replacement in femoral neck fracture in the elderly: results and review of the literature. Indian J Orthop. 2008; 42(1): 61-67. https://doi.org/10.4103/0019-5413.38583

21. Malkani AL, Dilworth B, Ong K, Baykal D, Lau E, Mackin TN, et al. High risk of readmission in octogenarians undergoing primary hip arthroplasty. Clin Orthop Relat Res. 2017; 475(12): 2878-2888. https://doi.org/10.1007/s11999-017-5241-9

22. Haynes J, Nam D, Barrack RL. Obesity in total hip arthroplasty: does it make a difference?. Bone Joint J. 2017; 99-B(1 Suppl A): 31-36. https://doi.org/10.1302/0301-620X.99B1.BJJ-2016-0346.R1

23. Werner BC, Higgins MD, Pehlivan HC, Carothers JT, Browne JA. Super obesity is an independent risk factor for complications after primary total hip arthroplasty. J Arthroplasty. 2017; 32(2): 402-406. https://doi.org/10.1016/j.arth.2016.08.001

24. Inacio MCS, Kritz-Silverstein D, Paxton EW, Fithian DC. Do patients lose weight after joint arthroplasty surgery?. A systematic review. Clinic Orthop. 2013; 471(1): 291-8. https://doi.org/10.1007/s11999-0122537-7

25. Parratte S, Pesenti S, Argenson JN. Obesity in orthopedics and trauma surgery. Orthopaedics \& Traumatology: Surgery \& Research. 2014; 100: 91-97. https://doi.org/10.1016/j.otsr.2013.11.003 
26. Meller MM, Toossi N, Gonzalez MH, Son MS, Lau EC, Johanson N. Surgical risks and costs of care are greater in patients who are super obese and undergoing THA. Clin Orthop Relat Res. 2016; 474(11): 2472-2481. https://doi.org/10.1007/s11999-016-5039-1

27. Fernandes L, Roos EM, Overgaard S, Villadsen A, Søgaard R. Supervised neuromuscular exercise prior to hip and knee replacement: 12-month clinical effect and cost-utility analysis alongside a randomised controlled trial. BMC Musculoskelet Disord. 2017; 18(1): 5. https://doi.org/10.1186/s12891-016-1369-0

28. Pozzi F, Madara K, Zeni JA Jr. A six-week supervised exercise and educational intervention after total hip arthroplasty: a case series. Int J Sports Phys Ther. 2017; 12(2): 259-272.

29. Nakayama T, Tsukada S, Hiyama T, Yamada T, Hirasawa N. Impact of active ankle movement frequency on velocity of lower limb venous flow following total hip arthroplasty. Adv Orthop. 2016; $2016: 7683272$. https://doi.org/10.1155/2016/7683272

30. Jogi P, Zecevic A, Overend TJ, Spaulding SJ, Kramer JF. Force-plate analyses of balance following a balance exercise program during acute post-operative phase in individuals with total hip and knee arthroplasty: a randomized clinical trial. SAGE Open Med. 2016; 4. https://doi.org/10.1177/2050312116675097

31. Judd DL, Dennis DA, Thomas AC, Wolfe P, Dayton MR, Stevens-Lapsley JE. Muscle strength and functional recovery during the first year after THA. Clinical Orthopaedics and Related Research. 2014; 472(2): 654664. https://doi.org/10.1007/s11999-013-3136-y

32. Reardon K, Galea M, Dennett X, Choong P, Byrne E. Quadriceps muscle wasting persists 5 months after total hip arthroplasty for osteoarthritis of the hip: a pilot study. Intern Med J. 2001; 31: 7-14. https://doi.org/10.1046/j.1445-5994.2001.00007.x

33. Sicard-Rosenbaum L, Light KE, Behrman AL. Gait, lower extremity strength, and self-assessed mobility after hip arthroplasty. J Gerontol A Biol Sci Med Sci. 2002; 57: M47-M51. https://doi.org/10.1093/gerona/57.1.M47

34. Bertocci GE, Munin MC, Frost KL, Burdett R, Wassinger CA, Fitzgerald SG. Isokinetic performanceafter total hip replacement. Am J Phys Med Rehabil. 2004; 83: 1-9. https://doi.org/10.1097/01.PHM.0000098047.26314.93

35. Holstege MS, Lindeboom R, Lucas C. Preoperative quadriceps strength as a predictor for short-term functional outcome after total hip replacement. Arch Phys Med Rehabil. 2011; 92: 236-241. https://doi.org/10.1016/j.apmr.2010.10.015

36. Nankaku M, Tsuboyama T, Aoyama T, Kuroda Y, Ikeguchi R, Matsuda S. Preoperative gluteus medius muscle atrophy as a predictor of walking ability after total hip arthroplasty. Phys Ther Res. 2016; 19(1): 8-12. https://doi.org/10.1298/ptr.E9884

37. Ikeda T, Jinno T, Aizawa J, Masuda T, Hirakawa K, Ninomiya K, et al. Effects of perioperative factors and hip geometry on hip abductor muscle strength during the first 6 months after anterolateral total hip arthroplasty. J Phys Ther Sci. 2017; 29(2): 295-300. https://doi.org/10.1589/jpts.29.295 